Acta Bot. Croat. 71 (1), 139-146, 2012

\title{
Fungal associations in gametophytes and young sporophytic roots of the fern Nephrolepis exaltata
}

\author{
Thangavelu MuthukumaR*, Kandasamy Prabha \\ Root and Soil Biology Laboratory, Department of Botany, Bharathiar University, \\ Coimbatore 641 046, Tamilnadu, India.
}

\begin{abstract}
Information is limited on the presence of endophytic fungal associations in green gametophytes and young sporophytes of extant ferns. Nothing is known about their presence in Polypodiales, the largest order among extant ferns. We screened chlorophyllous gametophytes and young sporophytes of Nephrolepis exaltata (L.) Schott., (Lomariopsidaceae, Polypodiales) growing naturally on soil, brick and coir for the presence of fungal endophytes. Gametophytes and young sporophytes growing on different substrates were invariably colonized by septate endophytic fungi. Hyaline or brown, regularly septate, inter- or intracellular hyphae with moniliform cells or microsclerotia characterized septate endophytic fungi. However, only the roots of young sporophytes growing on soil and bricks harboured arbuscular mycorrhizal (AM) fungi. The AM morphology conformed to the intermediate type with intracellular hyphal coils, arbusculate coils and intercellular hyphae. No AM fungal spores could be retrieved from the soil on which gametophytes and young sporophytes were growing. The observations in this study support the idea that the septate fungal endophytes could confer an ecological advantage on colonized individuals, especially on nutrient deficient substrates.
\end{abstract}

Key words: Nephrolepis exaltata; Gametophyte; Sporophyte; Arbuscular mycorrhiza; Septate endophytic fungi

\section{Introduction}

The life-cycle of ferns is unique as it alternates between two free-living and fundamentally different generations, the haploid gametophyte and the diploid sporophytes. Sporophytic roots of ferns are often associated with a wide range of fungi, the relationship varying from parasitism to mutualism (JOHNSON et al. 1997, NEUHAUSER and FARGIONE 2004). Investigations on the root fungal association in fern sporophytes indicates the widespread occurrence of arbuscular mycorrhizal (AM) association (MUTHUKUMAR and UDAIYAN 2000, WANG and QIU 2006). In addition, roots of fern sporophytes are associated with other fungal endophytes like the septate endophytic fungi (COOPER 1976, BERCH and KENDRICK

\footnotetext{
* Corresponding author, e-mail: tmkum@yahoo.com

Copyright ${ }^{\circledR} 2012$ by Acta Botanica Croatica, the Faculty of Science, University of Zagreb. All rights reserved.
} 
1982). Generally, reports on fungal associations in the gametophyte of pteridophytes are limited. The achlorophyllous subterranean gametophytes of taxa in Ophioglossaceae (Ophioglossales), Lycopodiaceae (Lycopodiales) and Psilotaceae (Psilotales) (WINTHER and FRIEDMAN 2007, 2008, 2009) are invariably colonized by endophytic fungi (READ et al. 2000). In contrast, photosynthetic green gametophytes of higher ferns are considered free from fungal colonization (READ et al. 2000). However, studies do indicate the occasional occurrence of aseptate endophytic fungi in gametophytes of Marattiaceae (Marattiales), Osmundaceae (Osmundales), Gleicheniaceae (Gleicheniales) and Schizaeaceae (Schizaeales) (CAMPbell 1908, Bower 1923, NAyAr and Kaur 1971, Boullard 1979, Schmid and OBERWInkLER 1995). TURNAU et al. (2005) reported the association of AM fungal endophytes Glomus tenue and Glomus intraradices with gametophytes and sporophytes of Pellaea viridis. More recently REYES-JARAMILLO et al. (2008) described mycorrhizal-like interaction in chlorophyllous gametophytes and young sporophytes of Dryopteris mиеnchii raised under laboratory conditions.

Polypodiales is the largest order among extant ferns, encompassing about 15 families. However, there is no information on the occurrence of fungal endophytes in gametophytes or young sporophytes of Polypodiales. Nephrolepis exaltata (L.) Schott., is an epiphytic or epilithic fern belonging to the family Lomariopsidaceae of the order Polypodiales (SMITH et al. 2006). It is native to tropical regions throughout the world, and in India, this fern is distributed in the Eastern Himalayas, and in south and central India. N. exaltata is one of the most popular and widely cultivated plants in home gardens. Medicinal uses of this fern include its use in menstrual disorders and as a birth-aid in parturition (CAMBIE and AsH 1994). Though $N$. exaltata is not a hyperaccumulator of heavy metals, it can still accumulate $200 \mathrm{mg} \mathrm{kg}^{-1}$ dry weight of arsenic (SRIVASTAVA et al. 2005). Spores of this fern occur in irrigation water causing the most serious weed problem in the cultivation of orchids (Ko et al. 2005). Nephrolepis exaltata is one of the pioneer species involved in recolonization of disturbed sites (TURRILL 1935). Information on the root fungal association in N. exaltata is limited. MUTHUKUMAR and UDAIYAN (2000) reported the presence of AM fungal association in sporophytes of $N$. exaltata growing in the Western Ghats of southern India. A few studies also indicate a growth response of in vitro raised $N$. exaltata to AM inoculation (Ponton et al. 1990, WANG et al. 1993). As, there is no information on the endophytic fungal associations in the naturally occurring chlorophyllous gametophytes and young sporophytes of taxa belonging to Polypodiales, we examined the gametophytes and young sporophytes of N. exaltata for endophytic fungal associations.

\section{Materials and methods}

A total of 219 chlorophyllous gametophytes and 150 young sporophytes growing naturally on different substrates (soil, brick, and coir) were collected during May 2010 from a home garden at Coimbatore, Tamil Nadu, India (Tab. 1, Figs. 1a-c). The gametophytes and sporophytes were growing on brick pieces (1-2 cm in diameter) and coir that were used as mulches to cover the soil surface of potted plants. The gametophytes and young sporophytes were confirmed to those of $N$. exaltata as there were no other fern taxa within a radius of $100 \mathrm{~m}$. Care was taken to retrieve the entire gametophytes and sporophytes along with their rhizoids and roots. The soil $(1 \mathrm{~cm}$ depth) on which the gametophytes and young sporophytes were growing were collected for assessing the presence of AM fungal spores. 
Tab. 1. Incidence of root fungal association in gametophytes and young sporophytes of Nephrolepis exaltata. $\mathbf{N}$ - total number of gametophytes/sporophytes examined; $\mathbf{M}$ - number of gametophytes/sporophytes with arbuscular mycorrhizal association; D - number of gametophytes/ sporophytes with septate fungal association. Given in parenthesis are the percentage of gametophytes/sporophytes with arbuscular mycorrhizal/ septate fungal association.

\begin{tabular}{cccccc}
\hline \multirow{2}{*}{ Substratum } & \multicolumn{2}{c}{ Gametophytes } & & \multicolumn{2}{c}{ Young sporophytes } \\
\cline { 2 - 3 } \cline { 5 - 6 } & $\mathrm{M} / \mathrm{N}$ & $\mathrm{D} / \mathrm{N}$ & & $\mathrm{M} / \mathrm{N}$ & $\mathrm{D} / \mathrm{N}$ \\
\hline Brick & $0 / 40(0 \%)$ & $36 / 40(90 \%)$ & & $28 / 60(47 \%)$ & $21 / 60(35 \%)$ \\
Coir & $0 / 110(0 \%)$ & $81 / 110(74 \%)$ & & $0 / 20(0 \%)$ & $11 / 20(55 \%)$ \\
Soil & $0 / 69(0 \%)$ & $43 / 69(62 \%)$ & & $66 / 70(94 \%)$ & $24 / 70(34 \%)$ \\
\hline
\end{tabular}

The gametophytes and young sporophytes were cleared in $2.5 \% \mathrm{KOH}$, acidified with 5 $\mathrm{N} \mathrm{HCl}$ and stained with trypan blue $(0.05 \%)$ in lactoglycerol (KOSKE and GEMMA 1989). The stained specimens were mounted on glass slides and examined under BX 51 Olympus trinocular compound microscope for the presence of AM fungal structures. Aseptate linear or coiled hyphae with arbuscules or arbusculate coils were considered AM. Hyaline or brown, regularly septate hyphae accompanied with moniliform cells or microsclerotia characterized septate fungal endophytes. Ten grams of the air-dried soil were subjected to modified wet-sieving and decanting technique (MUTHUKUMAR et al. 1996) to assess the presence of AM fungal spores.

\section{Results}

The gametophytes of $N$. exaltata were cordate, $0.25-0.55 \mathrm{~cm}$, dark green with an apical notch, one cell thick with the region posterior to the notch six to eight cells thick. Unicellular hairs occurred all over the surface of the gametophyte. Mature gametophytes were made up of polygonal cells containing chloroplasts, hermaphrodite, with archegonia distributed below the notch on the ventral surface and numerous hyaline to light brown rhizoids with interspersed antheridia at the pointed end (Fig. 1d, e). No AM fungal structure was found in gametophytes growing on different substrates (Tab. 1). In contrast, 62-90\% of the gametophytes from different substrates had septate fungal structures. Septate fungal colonization was frequent in gametophytes growing on brick followed by coir and soil. The endophytic fungal hyphae were mostly intracellular, regularly septate, hyaline or brown, 2-6 $\mu \mathrm{m}$ in diameter with moniliform cells or microsclerotia (Figs. $2 \mathrm{f}, \mathrm{g}$ ).

We found mycorrhization in roots of $47 \%$ and $94 \%$ of the young sporophytes collected from brick and soil respectively (Tab. 1). Similarly, 34-55\% of the young mycorrhizal sporophytes growing on different substrates also had the septate fungal association. AM fungal entry into roots was characterized by the presence of an appressorium on the root cell surface (Fig. 2a). AM fungal colonization in young sporophytic roots was characterized by aseptate hyphal coils and arbusculate coils with occasional intercellular hyphae (Fig. 2b-e). We did not observe any vesicles in the mycorrhizal roots of the young sporophytes. Although the roots of young sporophytes growing on coir lacked AM fungal colonization, roots of more than half $(55 \%)$ of the young sporophytes examined had septate fungal colonization. The septate fungal colonization in young sporophytes was similar to 


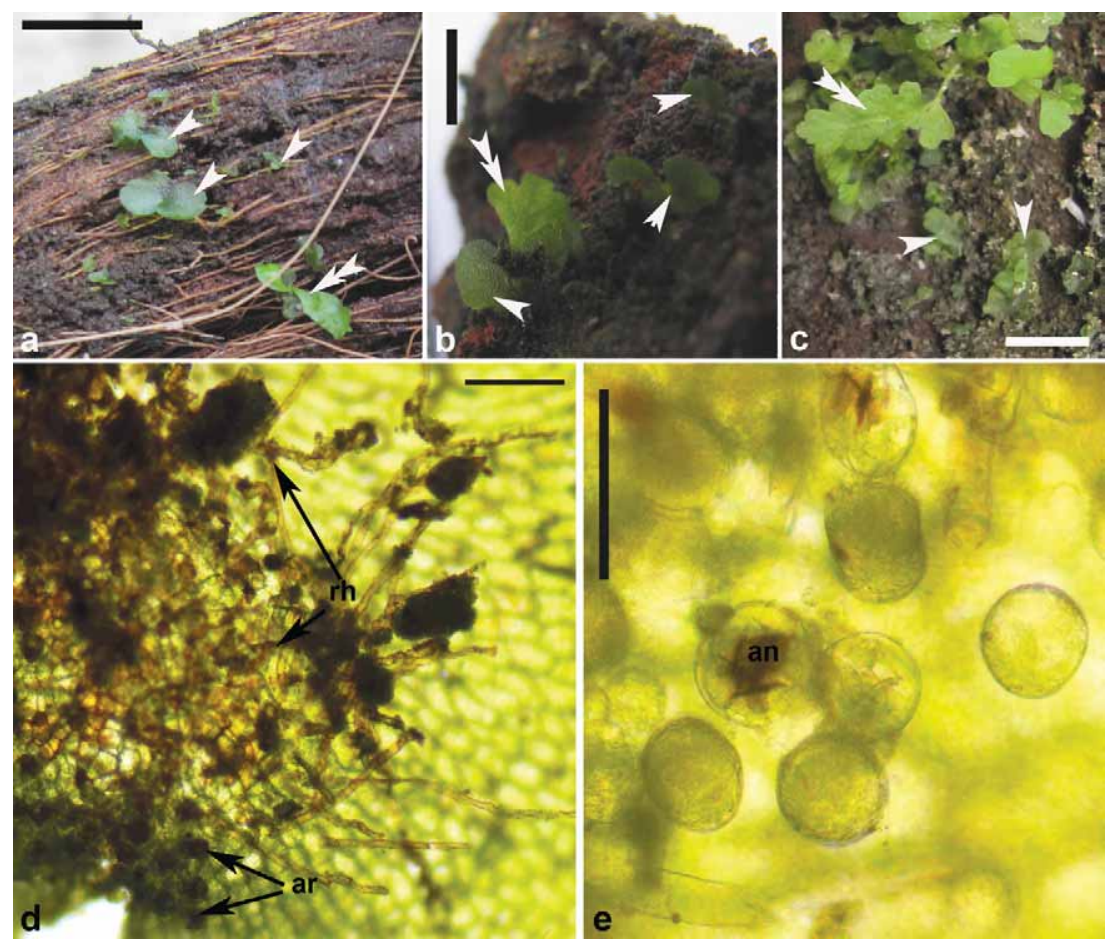

Fig. 1. Gametophytes and young sporophytes of Nephrolepis exaltata. Gametophytes (arrow head) and young sporophytes (double arrow head) growing on coir (a), brick (b) and soil (c). Rhizoids ( $(\mathrm{hh})$ and archegonia (ar) on ventral side of the gametophyte (d). Antheridium (an) on the ventral surface of the gametophyte (e). Scale bars denote $0.50 \mathrm{~cm}(\mathrm{a}-\mathrm{c}), 200 \mu \mathrm{m}(\mathrm{d})$ and $100 \mu \mathrm{m}(\mathrm{e})$.

those of the gametophytes except for slightly broader hyphae of $2-8 \mu \mathrm{m}$ in diameter. The proportion of sporophytes possessing septate endophytic fungi was low compared to the gametophytes (Tab. 1).

\section{Discussion}

The morphology of gametophytes of $N$. exaltata examined in the present study is similar to those reported by JAVALGEKAR and MAHABALE (1959). However, we did not observe any abnormal branched gametophytes bearing antheridiophore-like structures as observed by JAVALGEKAR and MAHABALE (1959). Observations of the present study disagree with the general view that the photosynthetic green gametophytes of ferns lack fungal association. Although the gametophytes of $N$. exaltata growing on different substrata lacked colonization by AM fungi, a large percentage (62-90\%) of these gametophytes was colonized by septate endophytic fungi. To our knowledge, the presence of septate endophytic fungal colonization in green fern gametophytes is being reported for the second time. SwATzELL et al. (1996) isolated a septate fungus from the gametophytes of Schizaea pusilla. However, the fungus failed to exhibit any specific recognition and rendering $10.3 \%$ of the host non-via- 


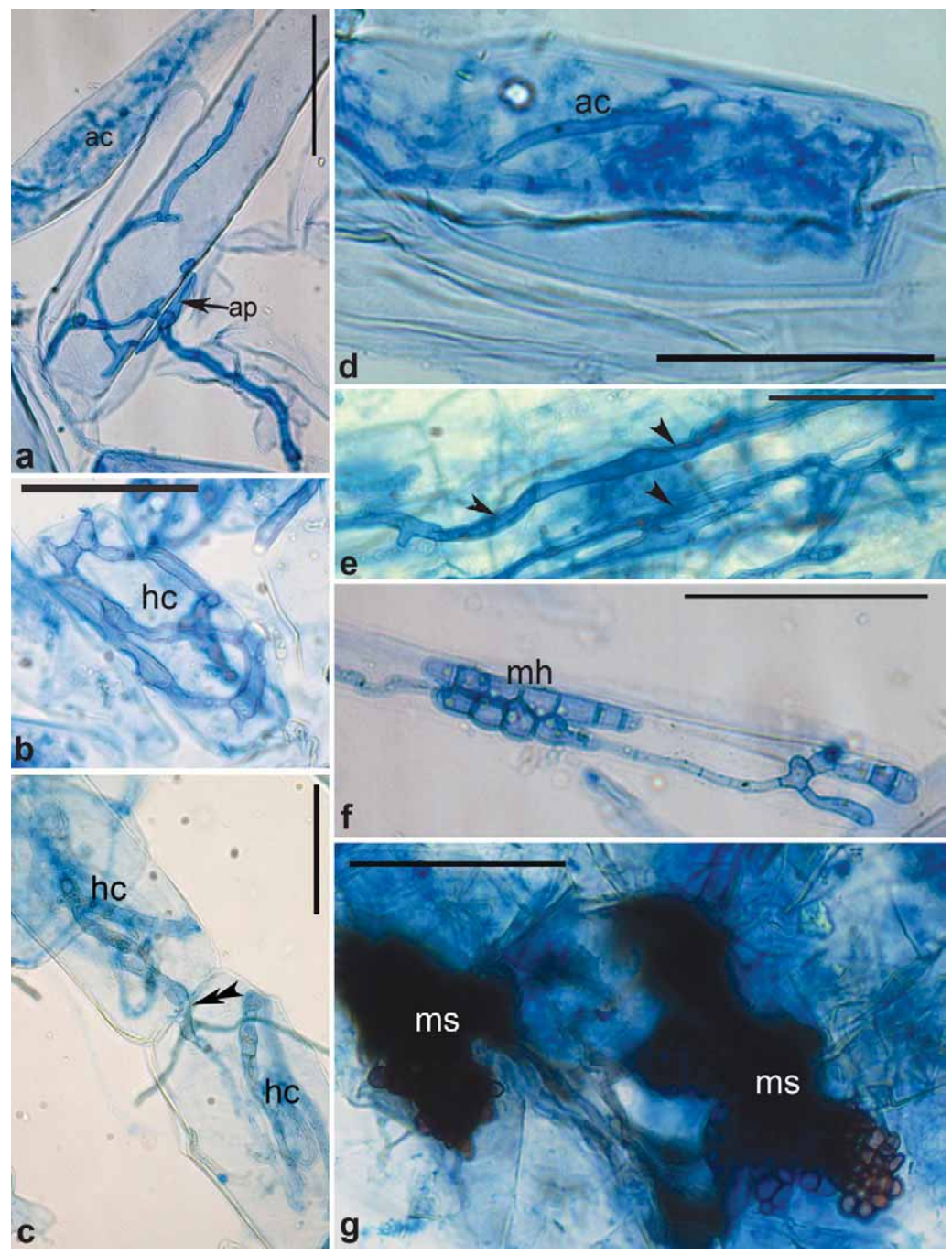

Fig. 2. Root fungal association in Nephrolepis exaltata. a-Appressorium (ap) and arbusculate coil (ac) in root of young sporophyte. $\mathbf{b}$ - Hyphal coil (hc) within root cortical cell. c-Cell to cell spread (double arrow head) of intracellular hyphal coils (hc) in young sporophyte root. d Arbusculate coil (ac) in root cortical cell. e - Intercellular aseptate hyphae (arrow heads) in roots of young saprophyte. $\mathbf{f}-$ Moniliform cells $(\mathrm{mh})$ in gametophyte growing on coir. $\mathbf{g}-$ Microsclerotia (ms) in gametophytic cells growing on coir. Scale bars denote $50 \mu \mathrm{m}$.

ble. The presence of septate endophytic fungal structures like moniliform hyphae and microsclerotia indicates that the fern gametophytes may also act as niches for endophytic fungal reproduction.

The lack of AM fungal colonization in the gametophytes of N. exaltata is in contrast to those studies (CAMPBell 1908, Bower 1923, Boullard 1979, SCHMID and OBERWINKLER 1995, TURNAU et al. 2005, REYES-JARAMILLO et al. 2008) where such an observation has 
been reported. Lack of AM propagules cannot be cited as a cause for the absence of AM association in these gametophytes as the primary roots of the young sporophytes growing on some of these substrates exhibited colonization by AM fungi. The presence of AM colonization in young roots of $N$. exaltata is in accordance with SCHMID and OBERWINKLER (1995), TURNAU et al. (2005) and REYES-JARAMILLO et al. (2008) where such an observation was made in young sporophytic roots of different fern species. AM morphology in primary roots of $N$. exaltata conform to an intermediate type characterized mostly by intracellular hyphal coils or arbusculate coils with limited intercellular hyphae as frequently observed in the roots of mature fern sporophytes (DICKSON et al. 2007). The presence of AM fungal colonization in the roots of young sporophytes without any retrievable spores indicates the involvement of propagule other than spores in mycorrhizal formation. Experimental evidence does indicate that the extramatrical hyphae arising from mycorrhizal roots can initiate mycorrhization (SMITH and READ 2008).

Dual occurrence of AM and septate endophytic fungi in N. exaltata young sporophyte root is similar to their presence in roots of mature fern sporophytes. Septate endophytic fungal colonization tends to dominate under circumstances not conducive to AM formation (HASElwandter and ReAd 1982). Though few studies (COOPER 1976, Turnau et al. 2005, PONTON et al. 1990, WANG et al. 1993) do indicate the role of AM fungi on growth of ferns, there is no information on the role of the septate endophytic fungi on fern development and growth. We suspect a greater role of septate endophytic fungi in gametophyte and sporophyte development in ferns as spores of ferns like $N$. exaltata often develop on substrates other than soil where AM inoculum is rare or absent. Further investigations on the role of septate endophytic fungi would draw a clear picture of the relationship among these fungi and fern gametophytes.

\section{References}

BERCH, M., KENDRICK, B., 1982: Vesicular arbuscular mycorrhizae of Southern Ontario ferns and fern-allies. Mycologia 74, 769-776.

Boullard, B., 1979: Consideration sur la symbiosefongique chez les Pteridophytes. Syllogeus 19, 1-59.

BOWER, F. O., 1923: The ferns, 1. Cambridge University Press, Cambridge.

CAMBIE, R. C., ASH, J., 1994: Fijian medicinal plants. CSIRO, Canberra, Australia.

CAMPBELl, D. H., 1908: Symbiosis in fern prothallia. The American Naturalist 42, $154-165$.

COOPER, K. M., 1976: A field survey of mycorrhizas in New Zealand ferns. New Zealand Journal of Botany 14, 169-181.

DicKSON, S., SMith, F. A., SMITH, S. E, 2007: Structural differences in arbuscular mycorrhizal symbiosis. More than 100 years after Gallaud, where next? Mycorrhiza 17, 375-393.

HASELWANDTER, K., READ, D. J., 1982: The significance of a root-fungus association in two Carex species of high-alpine plant communities. Oecologia 53, 352-354.

JAVALGEKAR, S. R., MAHABALE, T. S., 1959: Germination of spores and prothalli in two species of Nephrolepis, N. exaltata Schott., and N. acuta Presl. Proceedings of the National Institute of Science India 25, 333-338. 
Johnson, N. C., Graham, J. H., Smith, F. A., 1997: Functioning of mycorrhizal associations along the mutualism-parasitism continuum. New Phytologist 135, 575-585.

Ko, W-H., Ko, S. S., CHEN, M., 2005: Origin and control of fern weeds in orchid production in greenhouse in Hawaii. Crop Protection 24, 487-490.

Koske, R. E., Gemma, J. N., 1989: A modified procedure for staining roots to detect VA-mycorrhizas. Mycological Research 92, 486-488.

Muthukumar, T., UdAiYAn, K., MANiAn, S., 1996: Vesicular - arbuscular mycorrhizae in tropical sedges of Southern India. Biology and Fertility of Soils 22, 96-100.

MuthuKUMAR, T., UdAIYAN, K., 2000: Vesicular arbuscular mycorrhizae in pteridophytes of Western Ghats, Southern India. Phytomorphology 50,132-142.

NAYAR, B. K., KAUR, S., 1971: Gametophytes of homosporus ferns. Botanical Review 37, 295-396.

Neuhauser, C., Faragione, J. E., 2004: A mutualism-parasitism continuum model and its application to plant-mycorrhizae interactions. Ecological Modelling 177, 331-352.

Ponton, F., Piche, Y., Parent, S., Caron, M., 1990: Use of vesicular-arbuscular mycorrhizae in Boston fern production. II. Evaluation of four inocula. Horticultural Science $25,416-419$.

Read, D. J., Duckett, J. G., Francis, R., Ligrone, R., Russell, A., 2000: Symbiotic fungal associations in lower land plants. Philosophical Transactions of the Royal Society of London B-Biological Sciences 355, 815-831.

Reyes-Jaramillo, I., Camargo-Ricalde, S. L., Aquiahuatl-Ramos, M. A., 2008: Mycorrhizal-like interaction between gametophytes and young sporophytes of the fern Dryopteris muenchii (Filicales) and its fungal endophyte. Revista de Biologia Tropical 56, 1101-1107.

SCHMID, E., OBERwINKLER, F., 1995: A light- and electron-microscopic study on a vesicular-arbuscular host-fungus interaction in gametophytes and young sporophytes of the Gleicheniaceae (Filicales). New Phytologist 129, 317-324.

Smith, A. R., Pryer, K. M., Schuttplez, E., Korall, P., Schneider, H., Wolf, P. G., 2006: A classification of extant ferns. Taxon 55, 705-731.

Smith, S. E., Read, D. J., 2008: Mycorrhizal symbiosis. Academic Press Inc, San Diego.

Srivastava, M., MA, L. Q., Singh, N., Singh, S., 2005: Antioxidant responses of hyper accumulator and sensitive fern species to arsenic. Journal of Experimental Botany 56, $1335-1342$.

Swatzell, L. J., Powell, M. J., KIss, J. Z., 1996: The relationship of endophytic fungi to the gametophyte of the fern Schizaea pusilla. International Journal of Plant Sciences 157, 53-62.

Turnau, K., Anielska, T., Jurkiewicz, A., 2005: Mycothallic/mycorrhizal symbiosis of chlorophyllous gametophytes and sporophytes of a fern, Pellaea viridis (Forsk.) Prantl (Pellaeaceae, Pteridales). Mycorrhiza 15, 121-128.

Turrill, W. B., 1935: Krakatau and its problem. New Phytologist 34, 442.

WANG, B., QIU, L., 2006: Phylogenetic distribution and evolution of mycorrhizas in land plants. Mycorrhiza 16, 299-363. 
Wang, H., Parent, S., Gosselin, A., Desjardins, Y., 1993: Vesicular-arbuscular mycorrhizal peat-based substrates enhance symbiosis establishment and growth of three micropropagated species. Journal of the American Society for Horticultural Science 118, 896-901.

WinTHER, J. L., FRIEDMAN. W. E., 2007: Arbuscular mycorrhizal symbionts in Botrychium (Ophioglossaceae). American Journal of Botany 94, 1248-1255.

WinTHER, J. L., FrIEDMAN. W. E., 2008: Arbuscular mycorrhizal symbionts in Lycopodiaceae. New Phytologist 177, 790-801.

Winther, J. L., Friedman. W. E., 2009: Phylogenetic affinity of arbuscular mycorrhizal symbionts in Psilotum nudum. Journal of Plant Research 12, 485-496. 